\title{
Activation of transcription by v-myb: evidence for two different mechanisms
}

\author{
Karl-Heinz Klempnauer, Hannelore Arnold, and Horst Biedenkapp \\ Zentrum für Molekulare Biologie (ZMBH) der Universitä Heidelberg, Im Neuenheimer Feld 282, D-6900 Heidelberg, FRG
}

\begin{abstract}
The retroviral oncogene v-myb encodes a nuclear, sequence-specific DNA-binding protein. To investigate the possibility that v-myb encodes a transcriptional regulator, we used a transient cotransfection assay to explore the potential of $v$-myb to influence the expression of other genes. We found that expression of a chicken lysozyme promoter/CAT gene construct was activated by v-myb in the presence of myb-specific binding sites. Activation was not observed with a truncated v-myb protein lacking its DNA-binding domain. We also observed that expression of a hybrid human HSP70 promoter/CAT gene, lacking myb-specific binding sites, was activated by v-myb. However, in this case, the truncated v-myb protein, which lacked its DNA-binding domain, also activated HSP70/CAT expression, indicating that trans-activation of this gene construct was independent of the sequence-specific DNA-binding activity of the v-myb protein. These observations suggest that $v$-myb encodes a trans-activator and that activation of gene expression occurs by two different mechanisms, one of which involves specific binding of $\mathbf{v} \cdot \mathbf{m y b}$ protein to the regulated gene.
\end{abstract}

[Key Words: v-myb; nuclear oncogenes; trans-activation; specific DNA binding]

Received April 13, 1989; revised version accepted July 4, 1989.

The retroviral oncogene $\mathrm{v}-\mathrm{my} b$ encodes a $45-\mathrm{kD}$ protein, $\mathrm{p} 45^{\mathrm{v}-m y b}$, which is responsible for the potential of avian myeloblastosis virus (AMV) to transform myelomonocytic cells in vivo and in vitro (Klempnauer et al. 1982, 1983; Boyle et al. 1983; Moscovici and Moscovici 1983). The molecular mechanism of transformation by v-myb and the basis of its cell-type specificity are not known at present. $\mathrm{p} 45^{\mathrm{v}-\mathrm{m} y b}$ is a truncated and mutated form of the $75-\mathrm{kD}$ protein product of the chicken c-myb gene, p75 $5^{\mathrm{v}-m y b}$ (Klempnauer et al. 1983). c-myb expression is restricted largely to immature hematopoietic cells (Gonda et al. 1982; Westin et al. 1982; Sheiness and Gardinier 1984) and appears to be essential for their proliferation (Gewirtz and Calabretta 1988). Both v-myb and $\mathrm{c}-\mathrm{myb}$ encode nuclear DNA-binding proteins that are associated predominantly with chromatin and bind to DNA in vitro (Klempnauer and Sippel 1986). In vitro DNA binding by viral myb protein is specific for the sequence motif PyAAC $/ \mathrm{T} G$ (Biedenkapp et al. 1988), suggesting that myb proteins function by binding to specific target regions in the genome. However, no physiological in vivo targets for v-myb have been identified as yet.

c-myb genes have been highly conserved during evolution, particularly within the region that encodes their DNA-binding domain (Klempnauer and Sippel 1987; Peters et al. 1987). Genes encoding similar domains have been identified in vertebrates (Gonda and Bishop 1983; Gonda et al. 1985; Bender and Kuehl 1986; Gerondakis and Bishop 1986; Rosson and Reddy 1986; Slamon et al. 1986), in insects (Katzen et al. 1985; Peters et al. 1987), and in plants (Paz-Ares et al. 1987). The myb-related c1- gene of Zea mays (Paz-Ares et al. 1987) has been defined genetically as a regulator of genes, which are involved in anthocyanin biosynthesis. This suggests that myb genes encode a family of regulatory, sequence-specific DNAbinding proteins, which control the expression of certain target genes.

To explore the regulatory potential of v-myb, we used artificial gene constructs as model genes, cotransfected them with $\mathrm{v}$-myb expression vectors into eukaryotic cells, and investigated the effect of v-myb on the activity of these model genes. Our results show that v-myb activates gene expression by two different mechanisms. Expression of hybrid HSP70/CAT /chloramphenicol acetyltransferase) gene constructs is activated by $\mathrm{v}-m y b$ in a DNA-binding-independent fashion. In contrast, a gene construct containing myb-specific DNA-binding sites upstream of the chicken lysozyme promoter is activated by v-my $b$ in a DNA-binding-dependent fashion. This latter observation provides the first evidence that $\mathrm{v}-m y b$ protein binds directly to target genes to stimulate their expression.

Results

$v$-myb encodes a trans-activating activity

To investigate the regulatory potential of v-myb, we cotransfected expression vectors for $\mathrm{v}$-myb protein with hybrid gene constructs, containing indicator genes (coding for CAT or luciferase), fused to promoter regions of interest. The structure of the $\mathrm{v}-$ myb expression vectors is outlined in Figure 1A. After transfection of the 
A

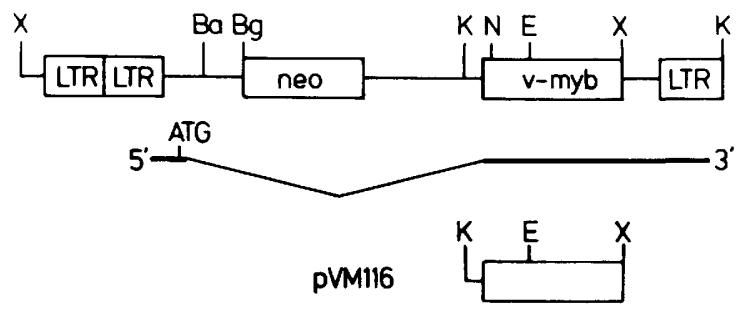

pVM111

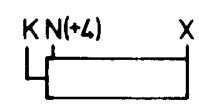

pVM130
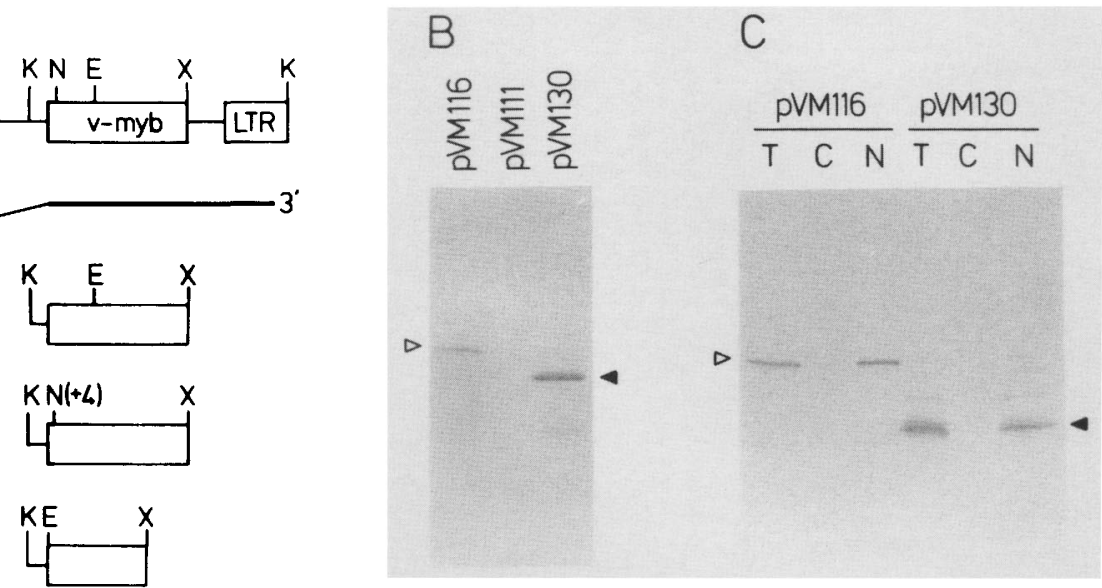

Figure 1. Expression of v-myb. (A) v-myb expression vectors used in this study. (Top) The general structure of the expression vectors and the spliced mRNA encoding v-myb. The ATG codon indicated is the gag gene ATG that provides the translational start for the $\mathrm{v}-\mathrm{myb}$ protein in AMV and in the expression vectors (Klempnauer et al. 1983). pVM116 encodes a full-length v-myb protein. pVM111 contains a 4-bp insert at the $N c o$ site $(\mathrm{N})$ close to the start of the v-myb-coding region. pVMl30 encodes an amino-terminally truncated v-myb protein lacking sequences $5^{\prime}$ to the EcoRI (E) site in v-myb. Other restriction sites are $B a m H I(B a) ; B g l I I(B g) ; K p n I$ $(\mathrm{K})$, and $\mathrm{XbaI}(\mathrm{X})$. (Only relevant restriction sites are shown). (B) Western blot analysis of quail fibroblasts transfected with $5 \mu \mathrm{g}$ each of the vectors described in $A$. (C) Western blot analysis of subcellular fractions of quail fibroblasts transfected with $5 \mu \mathrm{g}$ each of pVM116 or pVM130. (T) Unfractionated cells; (C) cytoplasmic fraction; (N) nuclear fraction. In $B$ and $C$, myb proteins was visualized by immunostaining with the myb-specific mAb myb2-2 (Evan et al. 1984). Full-length and truncated v-myb proteins are marked by open and closed arrowheads, respectively.

quail fibroblast cell line QT6 (Moscovici et al. 1977), myb protein could be detected by Western blotting with the myb-specific mAb myb2-2 (Fig. 1B; Evan et al. 1984). A control vector, containing a frameshift mutation in the v-myb-coding region close to its 5 ' end, did not yield detectable myb protein after transfection. Figure 1C shows that even after deletion of the amino-terminal region harboring the $\mathrm{v}-\mathrm{myb}$ DNA-binding domain, most of the expressed myb protein was transported to the cell nucleus, suggesting that a nuclear localization signal resides in the carboxy-terminal portion of the v-myb protein. This observation is in contrast to a previous report, which suggested the existence of a nuclear localization signal in the amino-terminal, highly conserved region of the v-myb protein by showing that deletion of this region abolished nuclear localization (Ibanez and Lipsick 1988). Presently, we have no explanation for this discrepancy.

In initial experiments we tested the influence of $\mathrm{v}-m y b$ on the expression of a panel of different gene constructs, whose structures are outlined in Figure 2A. Representative transfections, routinely performed in duplicate, are illustrated in Figure 2B-G. There was either no influence of v-myb on the expression of the transfected test gene (e.g., SV40-CAT, SV40-luciferase, or chicken LYSCAT) or v-myb stimulated the expression of the reporter gene (human and Drosophila HSP70/CAT). Activation HSP70/CAT expression is unlikely to be a stress response (caused, e.g., by the transfection procedure), because deletion of the heat shock response element, centered $\sim 100$ bp upstream of the transcriptional start site in the human HSP70 promoter and mediating stress re- sponse (Wu et al. 1986), did not abolish v-myb dependent activation (Fig. 2F).

To demonstrate that the v-myb-induced activation of HSP70/CAT expression was due to an increase in the level of transcripts initiated at the HSP70 promoter, we performed nuclease S1 mapping analyses of RNA isolated from transfected cells. As illustrated in Figure 3, the amount of mRNA changed in parallel to the CAT activity. Thus, $\mathrm{v}-\mathrm{my} b$ appeared to act on the level of transcription or to affect RNA stability or transport.

The experiments described thus far have been performed with the quail fibroblast cell line QT6. These cells do not express endogenous c-myb and are transfected efficiently. However, like chicken fibroblasts, quail fibroblasts cannot be transformed by AMV. Therefore, we were concerned that the trans-activating activity of $\mathrm{v}$-myb observed in QT6 cells did not mirror myb function in a myeloid cell transformed by v-myb. We repeated some of the transfection experiments using MC29-transformed chicken macrophages, which can be transformed by v-myb (Ness et al. 1987). Like QT6 cells, $\mathrm{HBCI}$ cells do not express detectable endogenous c-myb protein; however, transfection of $\mathrm{HBCI}$ cells was $\sim 10$ fold less efficient when compared with QT6 cells. The experiment illustrated in Figure 4 showed that v-myb activated HSP70/CAT expression to a similar extent in both HBCI and QT6 cells. Gene constructs that were not affected by v-myb in QT6 cells also were not affected when transfected into HBCI cells (data not shown). These experiments suggested that the trans-activating potential of v-myb is similar in a target and a nontarget cell. 
A

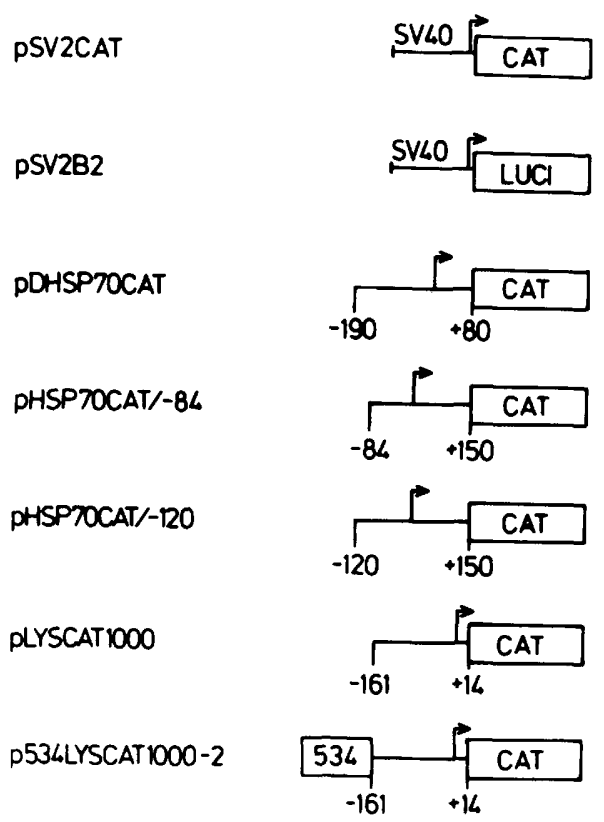

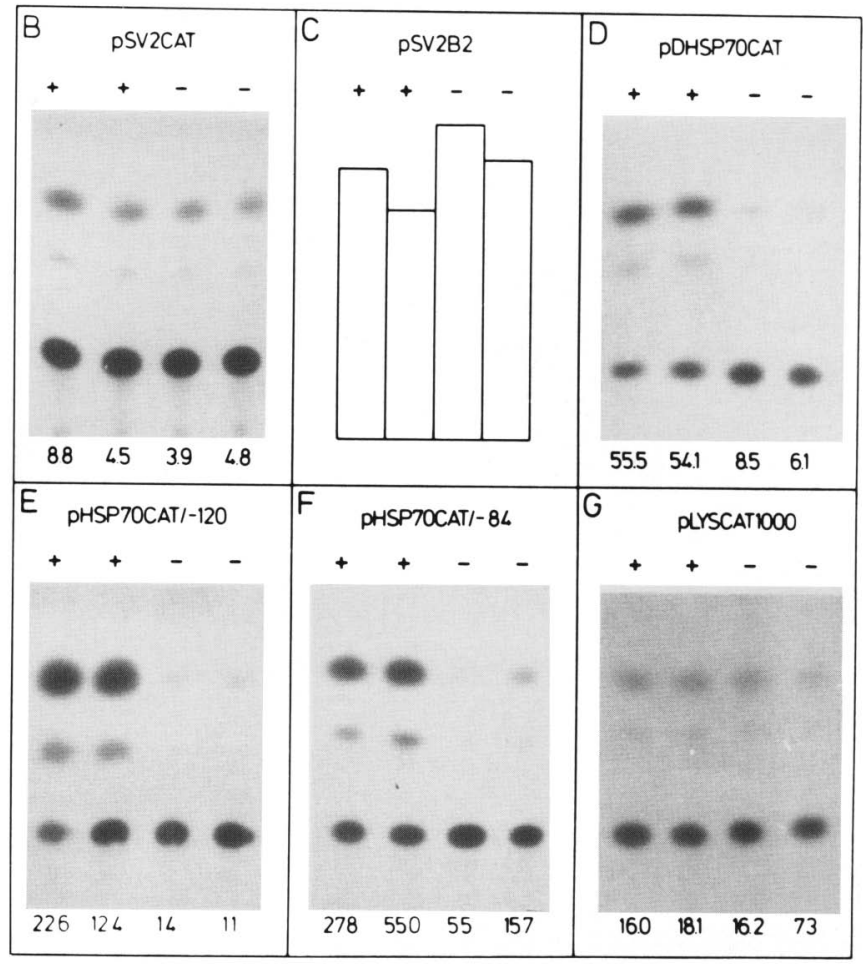

Figure 2. Trans-activation by v-myb. $(A \mid$ Schematic illustration of reporter plasmids used in this study. Numbers below the constructs refer to positions relative to transcriptional start sites, marked by arrows. pSV2CAT and pSV2B2 contain the SV40 early promoter and enhancer fused to the CAT- or luciferase-coding regions, respectively. pDHSP70CAT contains the promoter region of a Drosophila HSP70 gene (Amin et al. 1985). Other HSP70/CAT plasmids contain the promoter region of the human HSP70 gene (Kaddurah-Daouk et al. 1987). pLYSCAT constructs contain the promoter region of the chicken lysozyme gene (Theisen et al. 1986). (534) A sequence to which v-myb protein binds in vitro (Biedenkapp et al. 1988). (B-G) Different reporter plasmids (1 $\mu$ in $B$ and $C ; 5$ $\mu \mathrm{g}$ in $D-G)$ were cotransfected with pVM116 $(+)$ or pVM111 $(-)(5 \mu \mathrm{g}$ of each) and with $2 \mu \mathrm{g}$ each of pSV2B2 $(B$, and $D-G)$ or pSV2CAT $(C)$ into quail fibroblasts. Cells were harvested and analyzed $24 \mathrm{hr}$ after transfection. Numbers below lanes indicate percent conversion of chloramphenicol to acetylated derivatives. In $(C)$ Relative luciferase activities are indicated by the size of the columns. Each lane represents an individual cell culture dish. Transfection efficiencies were normalized by analyzing the activities of cotransfected pSV2B2 $(B$, and $D-G)$ and pSV2CAT $(C)$ gene constructs.

DNA binding of $v$-myb protein is not required for activation of HSP70/CAT expression

Previously, we have shown that v-myb encodes a sequence-specific DNA-binding protein, recognizing the sequence motif $P y A A C G / T G$ (Biedenkapp et al. 1988). DNA-binding studies with the HSP70 promoter region contained in plasmid pHSP70CAT/ -120 have not yielded any evidence for specific binding of $\mathrm{v}-m y b$ protein to the HSP70 promoter (data not shown). This lack of specific binding is consistent with a lack of $m y b$ recognition motifs from the HSP70 promoter. Therefore, it was interesting to investigate whether v-myb-induced activation of HSP70/CAT expression is dependent on the sequence-specific DNA-binding function of the $\mathrm{v}-m y b$ protein. To address this question, we cotransfected the HSP70/CAT gene construct with a v-myb expression vector (pVMl30), encoding an amino-terminally truncated version of the $\mathrm{v}-m y b$ protein. The truncated protein lacks the highly conserved DNA-binding domain and does not bind to DNA (Klempnauer and Sippel 1987; Peters et al. 1987); as shown in Figure 1, this protein is made in similar quantities as the fulllength v-my $b$ protein and is present in the nucleus. The experiment illustrated in Figure 5 demonstrated that the amino-terminally truncated protein trans-activated the HSP70/CAT gene construct quite efficiently when compared to the full-length $\mathrm{v}-\mathrm{my} b$ protein, indicating that DNA binding of $v-m y b$ protein was not required for activation of HSP70/CAT expression.

\section{A $v$-myb-binding site confers $\mathrm{v}$-myb responsiveness to a reporter gene}

The lack of a requirement for specific DNA binding in activation of HSP70/CAT expression by v-myb raised the question of whether specific DNA binding by $v-m y b$ protein to its cognate binding sites plays a role in gene regulation at all. Previously, we isolated myb-specific in vitro DNA-binding sites from the chicken genome (Biedenkapp et al. 1988). The availability of these sequences allowed us to test whether the presence of myb-specific binding sites affects the $m y b$-responsiveness of reporter genes. One of the myb-binding sequences, designated 

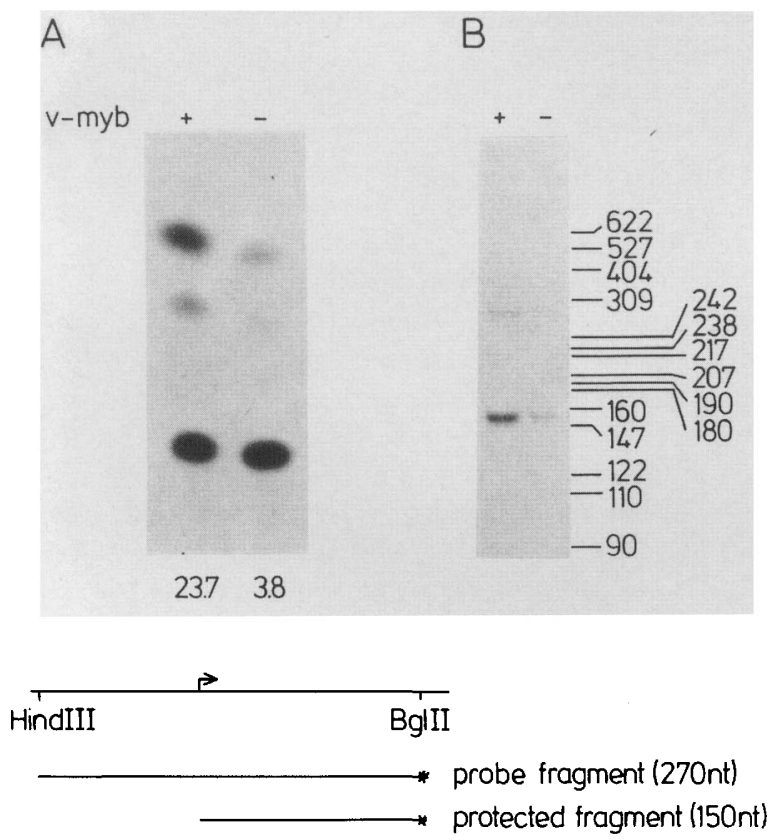

Figure 3. Nuclease S1 mapping of HSP70/CAT transcripts. $(A)$ CAT assay of quail fibroblasts transfected with pHSP70CAT/ $-120(3 \mu \mathrm{g}), \mathrm{pSV} 2 \mathrm{~B} 2(2 \mu \mathrm{g})$, and pVM116 $(+)$ or pVM111 $(-)(5$ $\mu \mathrm{g}$ each). Cells were harvested $24 \mathrm{hr}$ after transfection. Transfection efficiencies were normalized by analyzing the activity of the cotransfected pSV2B2 gene construct. Numbers below lanes indicate percent conversion of chloramphenicol to acetylated derivatives. Each lane represents two separately transfected cell culture dishes pooled at the time they were harvested. $(B)$ Nuclease S1 mapping of RNA isolated from the transfected cells shown in $A$. The upper band is the full-length probe fragment, and the lower band is the promoter-specific S1resistant fragment. The mapping strategy is outlined at the bottom. (Right) Sizes and positions of length markers.

534 (Biedenkapp et al. 1988), was cloned upstream of the chicken lysozyme promoter region in the pLYSCAT1000 gene construct. As described before, the 534 sequence element contains several v-myb consensus binding motifs recognized by $\mathrm{v}-m y b$ protein in vitro (Biedenkapp et al. 1988). Expression of the original gene construct lacking binding sites was affected only slightly by v-myb (Figs. $2 \mathrm{G}$ and $6 \mathrm{~B}$ ). However, in the presence of the v-myb-binding sites (p534LYSCAT1000-2), CAT expression was activated by $\mathrm{v}-m y b$ between 10 - and 20 fold, demonstrating that the $m y b$-binding sites conferred myb responsiveness to the chicken lysozyme promoter/ CAT gene construct. Transfection of HBCI cells instead of QT6 cells showed a similar activation of p534LYSCAT1000-2 expression, suggesting again that the trans-activating activity of $\mathrm{v}-m y b$ is similar in both cell types (data not shown). Analysis of RNA isolated from transfected cells showed that the myb-induced activation of expression was accompanied by increased abundance of transcripts initiated at the chicken lysozyme promoter (Fig. 6C). If, as we assume, v-myb protein activates p534LYSCAT1000-2 expression by interacting with its binding sites, we would expect a truncated $\mathrm{v}-m y b$ protein, lacking its DNA-binding domain, to be inactive in stimulating expression of the p534LYSCAT1000-2 gene construct. To demonstrate that the my $b$-induced activation of p534LYSCAT1000-2 expression required the $\mathrm{v}-m y b$ DNA-binding domain and therefore was qualitatively different from activation of HSP70/CAT expression, we tested the ability of the amino-terminally truncated $\mathrm{v}-m y b$ protein to activate expression of the p534LYSCAT1000-2 gene construct. Figure 6D shows that the truncated $\mathrm{v}-m y b$ protein, lacking its DNA-binding domain, did not stimulate expression of p534LYSCAT1000-2. This strongly suggested that activation of expression of this gene construct was due to specific binding of $\mathrm{v}-m y b$ protein to its cognate binding sites.

\section{Discussion}

The retroviral oncogene v-myb encodes a nuclear, sequence-specific DNA-binding protein (Biedenkapp et al. 1988); therefore it is possible that the v-myb protein directly interacts with certain target genes to regulate their expression. This hypothesis is consistent with the finding that the myb-related $c 1$ gene of Zea mays is a regulatory gene (Paz-Ares et al. 1987) and that one of the genes regulated by $c 1$, the maize $a 1$ gene, is associated with myb-binding sites (Biedenkapp et al. 1988; K.-H. Klempnauer, H. Arnold, and H. Biedenkapp, unpubl.). Because target genes for $\mathrm{v}-\mathrm{my} b$ have not been identified yet, we explored the regulatory potential of $\mathrm{v}-m y b$ by an indirect strategy, namely by testing the effect of $\mathrm{v}-m y b$ on the expression of various hybrid gene constructs.

The results presented here show that as with other nuclear oncogenes, such as jun (Bohmann et al. 1987;

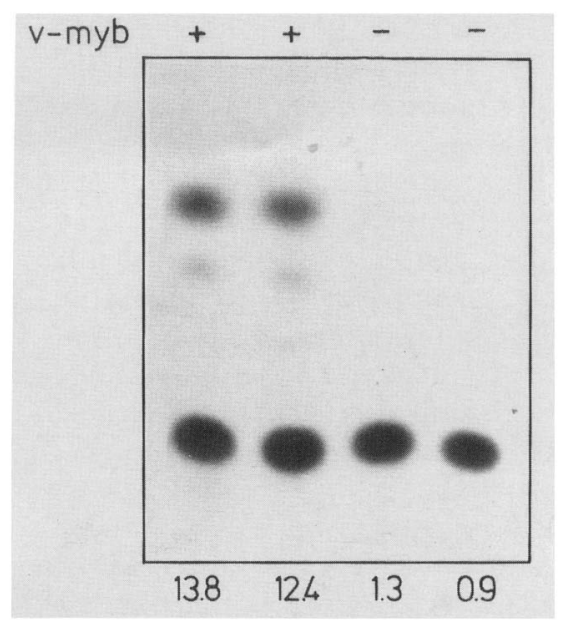

Figure 4. Activation of human HSP70/CAT expression in HBCI cells. HBCI cells were transfected with pHSP70CAT/ $-120(3 \mu \mathrm{g}), \mathrm{pSV} 2 \mathrm{~B} 2(2 \mu \mathrm{g})$, and pVM116 $(+)$ or pVM111 (-) $(5$ $\mu \mathrm{g}$ each). Cells were harvested $24 \mathrm{hr}$ later. Transfection efficiencies were normalized by analyzing the activity of the cotransfected pSV2B2 gene construct. Numbers indicate percent conversion of chloramphenicol to acetylated derivatives. Each lane represents a single transfected cell culture dish. 


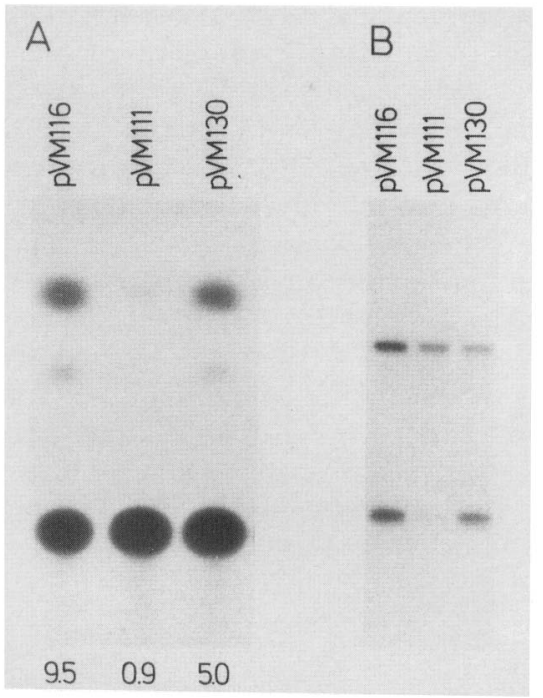

Figure 5. Activation of human HSP70/CAT expression by a truncated v-myb protein. $(A) \mathrm{CAT}$ assays of quail fibroblasts transfected with pHSP70CAT/ $-120(3 \mu \mathrm{g})$, pSV2B2 $(2 \mu \mathrm{g})$, and the indicated $m y b$ expression vectors $(5 \mu \mathrm{g}$ each). Cells were harvested and analyzed $24 \mathrm{hr}$ after transfection. Transfection efficiencies were normalized by analyzing the activity of the cotransfected pSV2B2 gene construct. Numbers indicate percent conversion of chloramphenicol to acetylated derivatives. Each lane represents two separately transfected cell culture dishes pooled when they were harvested. $(B)$ Nuclease S1 mapping analysis of RNA isolated from the transfected cells shown in $A$. The upper and lower bands are the full-length probe fragment and the promoter-specific Sl-resistant fragment, respectively. The mapping strategy is the same as in Fig. 3.

Angel et al. 1988), fos (Setoyama et al. 1986; Chiu et al. 1988; Lucibello et al. 1988; Sassone-Corsi et al. 1988), and myc (Kingston et al. 1984; Kaddurah-Daouk et al. $1987), \mathrm{v}-$ myb encodes a trans-activating activity. Therefore, our findings are consistent with the possibility that the $\mathbf{v}-m y b$ protein is a transcriptional regulator and that oncogenic transformation by $\mathrm{v}-m y b$ may be brought about by deregulation of certain $\mathrm{v}-m y b$ target genes.

While this manuscript was in preparation, Nishina et al. (1989) demonstrated trans-activation by mouse c-myb. Our results extend the findings of these investigators in two directions. First, as discussed below, we show that specific DNA binding might be involved in trans-activation by myb. Second, we demonstrated a trans-activating activity of $\mathrm{v}-m y b$. Thus, it appears that the trans-activation function of myb has been preserved during generation of $\mathrm{v}-m y b$, suggesting that this activity is required for transformation.

Activation of gene expression by v-myb occurs by two different mechanisms. Our results show that specific in vitro DNA-binding sites for v-myb protein confer $m y b$ responsiveness to a chicken lysozyme promoter/CAT gene construct. In addition to requiring the presence of myb-binding sites, activation of expression depends on the presence of the DNA-binding domain in the v-myb protein. The simplest explanation of these results is that the $\mathrm{v}-m y b$ protein in vivo interacts with its cognate binding sites and, in doing so, increases the expression of the bound gene construct. These observations represent the first evidence that the $\mathrm{v}-m y b$ protein in vivo recognizes specific binding sites and that $\mathrm{v}-m y b$ can regulate expression of a gene by directly binding to it via specific DNA-binding sites. We do not know whether the $v$-myb-binding site we used is recognized efficiently in vivo or whether a precise arrangement of $m y b$-binding sites and other promoter elements is required for optimal activation by v-myb. These uncertainties may limit the degree of activation observed.

In contrast to the binding-site-dependent mode of activation, stimulation of HSP70/CAT expression by $\mathrm{v}-m y b$ does not require the sequence-specific DNAbinding function of $\mathrm{v}-m y b$. This conclusion is based on the observation that a truncated $\mathrm{v}-m y b$ protein, lacking the DNA-binding domain, is still active as a trans-activator of the HSP70/CAT gene. Thus, v-myb might be capable of activating expression of certain genes in a DNA-binding-independent mode. The potential to affect gene expression by two different mechanisms has interesting implications for the regulation of the myb transactivating function. If both activating activities are regulated separately, myb may be capable of controlling expression of different target genes independently of one another.

It is interesting that $\mathrm{v}-m y b$ functions as a trans-activator in a cell type that cannot be transformed by $\mathrm{v}-m y b$. We have no proof at present that the trans-activating activity of $\mathrm{v}-m y b$ is essential for cell transformation. If it is, however, our results suggest that the target cell specificity of $\mathrm{v}-m y b$ is unlikely to be due to production of nonfunctional v-myb protein in nontarget cells. It is perhaps more likely that cellular targets, such as DNA sequences with which the protein must interact for transformation to occur, are not accessible in nontarget cells. That $\mathrm{v}-m y b$ protein interacts with transfected binding sites in quail fibroblasts is not inconsistent with this view, because the accessibility of transfected sequences to the protein might be very different from that of the resident sequences.

Our experiments do not directly address the nature of the mechanisms by which $\mathrm{v}-m y b$ activates gene expression. Because the myb responsiveness of the lysozyme promoter/CAT gene construct was affected by sequences lying upstream of the mRNA start site and are therefore not present in the RNA, it is likely that the $\mathrm{v}-m y b$ activates expression of this gene construct by increasing its transcription, rather than by affecting transport of half-life of the RNA. In case of the myb-binding site independent mode of activation, it is possible that v-myb acts on the level of transcription (e.g., by influencing the activities of certain transcription factors directly or indirectly). However, it would also be consistent with our data if v-myb activated HSP70/CAT expression by affecting transport or half-life of the HSP70/ CAT RNA. Identification of HSP70/CAT sequences that confer $m y b$ responsiveness should provide a means of resolving this question. 
$A$

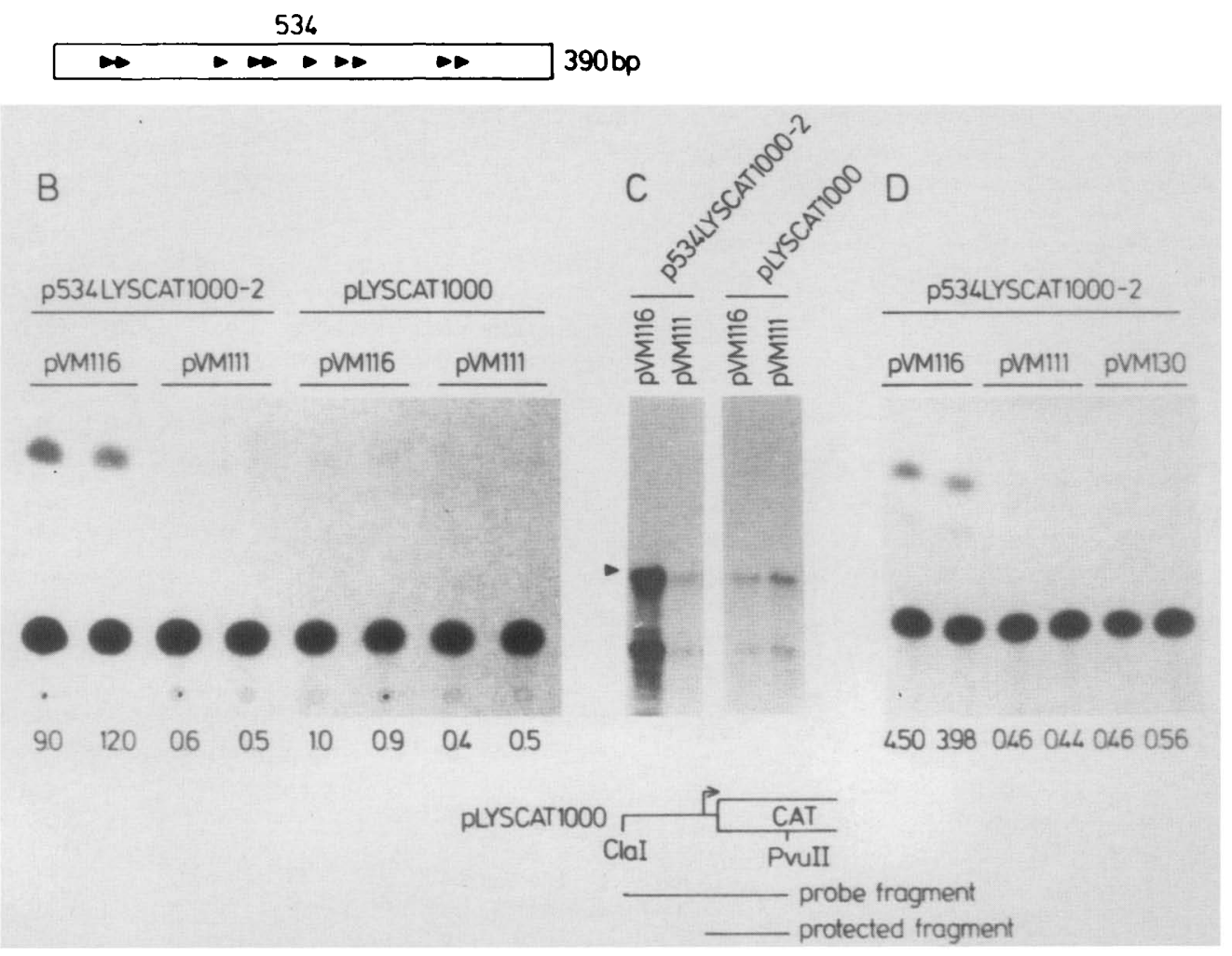

Figure 6. Effect of v-myb-binding sites on activation of chicken LSYCAT expression. (A) Location of myb consensus binding motifs (arrowheads) in the chicken genomic sequence 534 (Biedenkapp et al. 1988). (B and D). CAT assays of quail fibroblasts, transfected with the indicated DNAs (5 $\mu \mathrm{g}$ of each) and with $2 \mu \mathrm{g}$ of pSV2B2 to monitor transfection efficiencies. Each lane represents a single transfected cell culture dish. Numbers indicate percent conversion of chloramphenicol to acetylated derivatives. Transfection efficiencies were normalized by analyzing the activity of the cotransfected pSV2B2 gene construct. $(C)$ Ribonuclease protection analysis of RNA isolated from quail fibroblasts transfected as indicated. Each lane represents two separately transfected cell culture dishes pooled at the time they were harvested. The arrowhead indicates to the RNase-resistant promoter-specific fragment. The band below presumably results from protection of a less than full-length probe molecule. The mapping strategy is outlined at bottom. In all experiments, cells were harvested $24 \mathrm{hr}$ after transfection.

\section{Materials and methods}

\section{Cells and antibodies}

QT6 is a line of chemically transformed quail fibroblasts (Moscovici et al. 1977). HBCI is a line of MC29-transformed chicken macrophages, kindly provided by $\mathrm{H}$. Beug. All cells were grown in Iscove's modified Dulbecco's minimal Eagle's medium (DMEM), supplemented with $2 \%$ chicken serum and $8 \%$ fetal calf serum. The myb-specific mAb myb2-2 has been described previously (Evan et al. 1984).

\section{Western blotting}

Western blotting was performed as described previously (Klempnauer et al. 1986).

\section{Plasmids}

An expression vector for full-length $\mathrm{v}$-myb protein (pVM116) was constructed as follows. A $2.3-\mathrm{kb} X b a \mathrm{I}-B g I I I$ fragment, encompassing two tandem copies of the MAV-2 long terminal repeat (LTR) and adjoining gag sequences, was taken from a cloned copy of a myeloblastosis-associated virus /G. Ramsay,
D. Westaway, K.-H. Klempnauer, H.E. Varmus, and J.M. Bishop, unpubl.) and cloned upstream of a $2.5-\mathrm{kb} B g / I I-K p n I$ fragment of the clone pVM2 (Klempnauer et al. 1982), containing the $\mathrm{v}-m y b$ gene and flanking viral sequences including the downstream LTR of an integrated AMV. A 0.85-kb BamHI-BglII fragment of plasmid pKml8 (Beck et al. 1982), carrying the neomycin resistance gene, was inserted into the single $B g I I I$ site upstream of the v-myb gene. In cells carrying this vector, $\mathrm{v}-\mathrm{my} b$ is expressed from a spliced mRNA, as in the original AMV. Translation of the $\mathrm{v}-m y b$ protein starts at the gag ATG; thus, the protein encoded by pVM116 is identical to authentic p45 ${ }^{\mathrm{v}-\mathrm{myb}}$ encoded by AMV (Klempnauer et al. 1982). pVM111 was constructed by filling in the $5^{\prime}$ overhanging ends of a NcoI site located at the $5^{\prime}$ end of the v-myb-coding region, thereby creating a frameshift. To obtain pVM130, a HinfI site, GAATC, located exactly at the start of the v-myb-coding region (Klempnauer et al. 1982), was converted to an EcoRI site, GAATTC, and fused with the single EcoRI site within v-myb. The protein encoded by pVM130 lacks the amino-terminally located v-myb DNA-binding domain. Most reporter plasmids used in trans-activation experiments have been described previously (see legend to Fig. 2). pSV2B2, a derivative of pSV2CAT containing the firefly luciferase gene (De Wet et al. 1987) instead of the CAT gene, was a gift of C. Peters. 


\section{DNA transfection and CAT and luciferase assays}

DNA was transfected into QT6 or HBCI cells by the calcium phosphate coprecipitation method (Graham and van der Eb 1973), as modified by Theisen et al. (1986). Cell extracts to be used for enzyme assays were prepared by suspending the cells in $0.1 \mathrm{M}$ potassium phosphate $(\mathrm{pH} 7.8)$ and $1 \mathrm{~mm}$ dithioerythrol, freeze-thawing them three times, and spinning down debris. CAT and luciferase assays were performed as described (Theisen et al. 1986; De Wet et al. 1987). CAT activities were quantitated by measuring the amounts of the ${ }^{14} \mathrm{C}$-labeled chloramphenicol substrate and the acetylated products in a scintillation counter.

\section{RNA analyses}

Total cellular RNA was prepared as follows. Transfected cells were washed in PBS and lysed in $4 \mathrm{M}$ guanidinium thiocyanate, $0.5 \%$ sarcosyl, $25 \mathrm{~mm}$ sodium citrate $(\mathrm{pH} 7.0)$, and $1 \mathrm{mM} \beta$-mercaptoethanol. DNA was sheared by passing the lysate through a syringe until it was no longer viscous. Then the lysate was layered on the top of a cushion composed of $5.7 \mathrm{M} \mathrm{CsCl}, 50 \mathrm{~mm}$ sodium acetate (pH 5.4), and $50 \mathrm{~mm}$ EDTA and centrifuged in an SW 60 rotor at $36,000 \mathrm{rpm}$ at $20^{\circ} \mathrm{C}$ for $16 \mathrm{hr}$. The pelleted RNA was dissolved in $10 \mathrm{~mm}$ Tris- $\mathrm{HCl}(\mathrm{pH} 7.5)$ and $1 \mathrm{~mm}$ EDTA, ethanol-precipitated three times, and then used directly for $\mathrm{Sl}$ or ribonuclease protection studies. S1 mapping was performed as described (Theisen et al. 1986). The probe used for S1 mapping was a 270-bp BglII-HindIII fragment of plasmid pHSP70CAT/ -120 . This fragment encompasses the HSP70 promoter region from -120 to +150 bp (Kaddurah-Daouk et al. 1987). To generate a radiolabeled probe suitable for ribonuclease protection studies, a 330 -bp ClaI-PvuII fragment of plasmid pLYSCAT1000 (encompassing the $5^{\prime}$ end of the CAT gene and chicken lysozyme promoter sequences up to $-161 \mathrm{bp}$; Theisen et al. 1986) was cloned into the vector pBluescriptKSM13-. Then the DNA of this plasmid was linearized with $\mathrm{ClaI}$ and transcribed with T7 RNA polymerase. Hybridization of the probe to RNA and ribonuclease digestion were performed by published procedures (Melton et al. 1984).

\section{Acknowledgments}

We thank E. Beck, R. Kingston, C. Peters, G. Schütz, A. Stief, and $M$. Theisen for plasmids, and the members of the Sippel laboratory, especially C. Bonifer, A. Hecht, U. Kruse, and A.E. Sippel, for contributing stimulating discussions. This work was supported by grants from the Bundesministerium für Forschung und Technologie (BCT 0381/5) and the Deutsche Forschungsgemeinschaft (SFB229/A4).

\section{References}

Amin, I., R. Mestril, R. Lawson, H. Klapper, and R. Voellmy. 1985. The heat shock consensus sequence is not sufficient for hsp70 gene expression in Drosophila melanogaster. Mol. Cell. Biol. 5: 197-203.

Angel, P., E.A. Allegretto, S.T. Okino, K. Hattori, W.J. Boyle, T. Hunter, and M. Karin. 1988. The jun oncogene encodes a sequence-specific transactivator similar to AP-1. Nature 332: $166-171$.

Beck, E., G. Ludwig, E.A. Auerswald, B. Reiss, and H. Schaller. 1982. Nucleotide sequence and exact localization of the neomycin phosphotransferase gene from transposon Tn5. Gene 19: 327-336.

Bender, T.P. and W.M. Kuehl. 1986. Murine myb protoonco- gene mRNA: cDNA sequence and evidence for $5^{\prime}$ heterogeneity. Proc. Natl. Acad. Sci. 83: 3204-3208.

Biedenkapp, H., U. Borgmeyer, A.E. Sippel, and K.-H. Klempnauer. 1988. Viral myb oncogene encodes a sequence-specific DNA-binding activity. Nature 355: 835-837.

Bohmann, D., T.J. Bos, A. Admon, T. Nishimura, P.K. Vogt, and R. Tiian. 1987. Human proto-oncogene c-jun encodes a DNA-binding protein with structural and functional properties of transcription factor AP-1. Science 238: 1386-1392.

Boyle, W.J., J.S. Lipsick, E.P. Reddy, and M.A. Baluda. 1983. Identification of the leukemogenic protein of avian myeloblastosis virus and of its normal cellular homologue. Proc. Natl. Acad. Sci. 80: 2834-2838.

Chiu, R., W.J. Boyle, J. Meek, T. Smeal, T. Hunter, and M. Karin. 1988. The c-Fos protein interacts with c-Jun/AP-1 to stimulate transcription of AP-1 responsive genes. Cell 54: $541-552$.

De Wet, I., K.V. Wood, M. DeLuca, D.R. Helinski, and S. Subramani. 1987. Firefly luciferase gene: Structure and expression in mammalian cells. Mol. Cell. Biol. 7: 725-737.

Evan, G.I., G.K. Lewis, and J.M. Bishop. 1984. Isolation of monoclonal antibodies specific for products of avian oncogene myb. Mol. Cell. Biol. 4: 2843-2850.

Gerondakis, S. and J.M. Bishop. 1986. Structure of the protein encoded by the chicken proto-oncogene c-myb. Mol. Cell. Biol. 6: 3677-3684.

Gewirtz, A.M. and B. Calabretta. 1988. A c-myb antisense oligonucleotide inhibits normal human hematopoiesis in vitro. Science 242: 1303-1306.

Gonda, T.J. and J.M. Bishop. 1983. Structure and transcription of the cellular homolog $(c-m y b)$ of the avian myeloblastosis virus transforming gene $(\mathrm{v}-\mathrm{my} b)$. J. Virol. 46: 212-220.

Gonda, T.J., D.K. Sheiness, and J.M. Bishop. 1982. Transcripts from the cellular homologs of retroviral oncogenes: Distribution among chicken tissues. Mol. Cell. Biol. 2: 617-624.

Gonda, T.J., N.M. Gough, A.R. Dunn, and J. de Blaquiere. 1985. Nucleotide sequence of cDNA clones of the murine myb proto-oncogene. EMBO /. 4: 2003-2008.

Graham, F.L. and A.J. van der Eb. 1973. A new technique for the assay of infectivity of human adenovirus 5 DNA. Virology 52: $456-467$.

Ibanez, C.E. and J.S. Lipsick. 1988. Structural and functional domains of the $m y b$ oncogene: Requirements for nuclear transport, myeloid transformation, and colony formation. $J$. Virol. 62: 1981-1988.

Kaddurah-Daouk, R., J.M. Greene, A.S. Baldwin, and R.E. Kingston. 1987. Activation and repression of mammalian gene expression by the c-myc protein. Genes Dev. 1:347357.

Katzen, A.L., T.B. Kornberg, and J.M. Bishop. 1985. Isolation of the proto-oncogene c-myb from $D$. melanogaster. Cell 41: 449-456.

Kingston, R.E., A.S. Baldwin, and P.A. Sharp. 1984. Regulation of heat shock protein 70 gene expression by c-myc. Nature 312: $280-282$.

Klempnauer, K.-H. and A.E. Sippel. 1986. Subnuclear localization of proteins encoded by the oncogene v-myb and its cellular homolog c-myb. Mol. Cell. Biol. 6: 62-69.

Klempnauer, K.-H. and A.E. Sippel. 1987. The highly conserved amino-terminal region of the protein encoded by the $v-m y b$ oncogene functions as a DNA-binding domain. EMBO $I$. 6: $2719-2725$.

Klempnauer, K.-H., C. Bonifer, and A.E. Sippel. 1986. Identification and characterization of the protein encoded by the human c-myb proto-oncogene. EMBO I. 5: 1903-1911.

Klempnauer, K.-H., T.J. Gonda, and J.M. Bishop. 1982. Nucleo- 
tide sequence of the retroviral leukemia gene $\mathrm{v}-m y b$ and its cellular progenitor c-myb: The architecture of a transduced oncogene. Cell 31: 453-463.

Klempnauer, K.-H., G. Ramsay, J.M. Bishop, M.G. Moscovici, C. Moscovici, J.P. McGrath, and A.D. Levinson. 1983. The product of the retroviral transforming gene v-myb is a truncated version of the protein encoded by the cellular oncogene c-myb. Cell 33: 345-355.

Lucibello, F.C., M. Neuberg, J.B. Hunter, T. Jenuwein, M. Schuermann, R. Wallich, B. Stein, A. Schönthal, P. Herrlich, and R. Müller. 1988. Transactivation of gene expression by fos protein: Involvement of a binding site for the transcription factor AP-1. Oncogene 3: 43-51.

Melton, D.A., P.A. Krieg, M.R. Rebagliati, T. Maniatis, K. Zinn, and M.R. Green. 1984. Efficient in vitro synthesis of biologically active RNA and RNA hybridization probes from plasmids containing a bacteriophage SP6 promoter. Nucleic Acids Res. 12: 7035-7056.

Moscovici, M.G. and C. Moscovici. 1983. Isolation and characterization of a temperature-sensitive mutant of avian myeloblastosis virus. Proc. Natl. Acad. Sci. 80: 1421-1425.

Moscovici, C., M.G. Moscovici, H. Jiminez, M.M.C. Lai, M.J. Hayman, and P.K. Vogt. 1977. Continuous tissue culture cell lines derived from chemically induced tumors of Japanese quail. Cell 11: 95-103.

Ness, S.A., H. Beug, and T. Graf. 1987. V-myb dominance over $\mathrm{v}-\mathrm{my} b$ in doubly transfected chick myelomonocytic cells. Cell 51: 41-50.

Nishina, Y., H. Nakagoshi, F. Imamoto, T.J. Gonda, and S. Ishii. 1989. Trans-activation by the c-myb proto-oncogene. $\mathrm{Nu}$ cleic Acids Res. 17: 107-117.

Paz-Ares, J., D. Ghosal, U. Wienand, P.A. Peterson, and H. Saedler. 1987. The regulatory $c 1$ locus of Zea mays encodes a protein with homology to myb proto-oncogene products and with structural similarities to transcriptional activators. EMBO I. 6: 3553-3558.

Peter, C.W.B., A.E. Sippel, M. Vingron, and K.-H. Klempnauer. 1987. Drosophila and vertebrate myb proteins share two conserved regions, one of which functions as a DNAbinding domain. EMBO I. 6: 3085-3090.

Rosson, D. and E.P. Reddy. 1986. Nucleotide sequence of chicken c-myb complementary DNA and implications for myb oncogene activation. Nature 319: 604-606.

Sassone-Corsi, P., L.J. Ransone, W.W. Lamph, and I.M. Verma. 1988. Direct interaction between fos and jun nuclear oncoproteins: Role of the 'leucine zipper' domain. Nature 336: $692-695$.

Setoyama, D., R. Frunzio, G. Liau, M. Mudrij, and B. de Crombrugghe. 1986. Transcriptional activation encoded by the v-fos gene. Proc. Natl. Acad. Sci. 83: 3213-3217.

Sheiness, D. and M. Gardinier. 1984. Expression of a proto-oncogene (proto-myb) in hematopoietic tissues of mice. Mol. Cell. Biol. 4: 1206-1212.

Slamon, D.J., T.C. Boone, D.C. Murdock, D.E. Keith, M.F. Press, R.A. Larson, and L.M. Souza. 1986. Studies of the human c-myb gene and its product in acute human leukemias. Science 233: 347-351.

Theisen, M., A. Stief, and A.E. Sippel. 1986. The lysozyme enhancer: cell-specific activation of the chicken lysozyme gene by a far upstream element. EMBO I. 5: 719-724.

Westin, E.H., R.C. Gallo, S.K. Arya, A. Eva, L.M. Souza, M.A. Baluda, S.A. Aaronson, and F. Wong-Staal. 1982. Differential expression of the $a m v$ gene in human hematopoietic cells. Proc. Natl. Acad. Sci. 79: 2194-2196.

Wu, B.J., R.E. Kingston, and R.I. Morimoto. 1986. The human hsp70 promoter contains at least two distinct regulatory domains. Proc. Natl. Acad. Sci. 83: 629-633. 


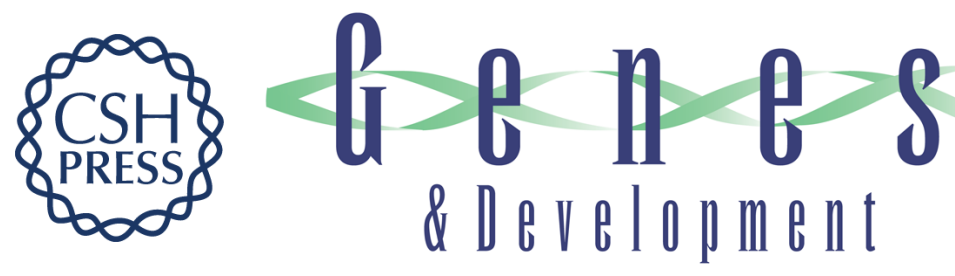

\section{Activation of transcription by v-myb: evidence for two different mechanisms.}

K H Klempnauer, H Arnold and H Biedenkapp

Genes Dev. 1989, 3:

Access the most recent version at doi:10.1101/gad.3.10.1582

References This article cites 41 articles, 19 of which can be accessed free at:

http://genesdev.cshlp.org/content/3/10/1582.full.html\#ref-list-1

License

Email Alerting

Service

Receive free email alerts when new articles cite this article - sign up in the box at the top right corner of the article or click here.

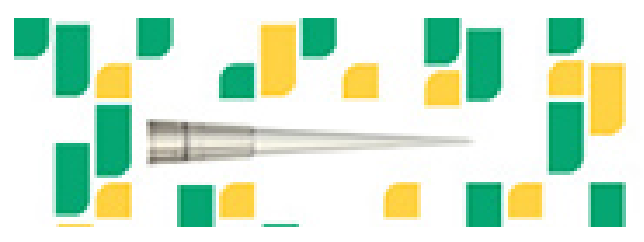

Focused on your science. 